\title{
PENGARUH LIKUIDITAS, RISIKO BISNIS, DAN PERTUMBUHAN PERUSAHAAN TERHADAP KEBIJAKAN DIVIDEN
}

\author{
Roshidayah $^{1}$, \\ Anita Wijayanti², \\ Suhendro ${ }^{3}$. \\ ${ }^{1}$ Fakultas Ekonomi, Universitas Islam Batik Surakarta \\ Email : rushidayah713@gmail.com \\ ${ }^{2}$ Fakultas Ekonomi, Universitas Islam Batik Surakarta \\ Email : itax_solo@yahoo.com \\ ${ }^{3}$ Fakultas Ekonomi, Universitas Islam Batik Surakarta \\ Email :dro_s@yahoo.com
}

\begin{abstract}
This study aims to examine and analyze the effect of liquidity, business risk, and company growth on dividend policy in property and real estate companies in 2015-2019 listed on the Indonesia Stock Exchange (BEI). The method used in this research is quantitative method. Sampling was done by purposive sampling was done by purposive sampling through several criteria, in order to obtain a sampling through several criteria, in order to obtain a sample of 46 companies. Hypothesis testing using multiple linear regression method. The results showed that the liquidity variable and business risk variables had an effect on dividend policy, but the company growth variable showed that the resuts had no effect on dividend policy.
\end{abstract}

Keywords : Liquidity, Business Risk, Company Growth, Dividend Policy

\section{PENDAHULUAN}

Investor yang menanamkan modalnya kepada sebuah perusahaan pasti mengharap akan adanya pengembalian investasinya, salah satunya yaitu berupa dividen. Sebuah perusahaan harus menentukan dengan tepat mengenai pembagian labanya. Jika perusahaan membagikan dividen lebih besar dibandingkan laba yang ditahan, maka akan mengurangi dana internal perusahaan yang harusnya dana tersebut bisa digunakan untuk membiayai aktivitas perusahaan. Tetapi, apabila dividen yang dibagikan lebih besar maka akan menarik investor untuk menanamkan sahamnya pada perusahaan (Enow \& Isaacs, 2018).

Kebijakan dividen dapat diketahui dengan melihat rasio Dividend Payaout Ratio, kecil besarnya DPR bisa mempengaruhi para pemegang saham dalam keputusan investasi, tetapi disisi lain bisa berpengaruh dengan kondisi keuangan perusahaannya. Tingkat laba yang dibagikan dalam bentuk deviden maka menunjukkan jika kondisi perusahaan tersebut keadaan sehat dan mempunyai prospek yang bagus dimasa yang akan datang sehingga membuat semakin menariknya calon investor. Perusahaan yang memutuskan membagikan labanya dengan bentuk dividen dapat mengurangi dana internalnya. Tetapi jika perusahaan memutuskan untuk menahan laba yang didapatkannya bisa mengakibatkan semakin besarnya kemampuan pembentukan dana internalnya (Sartono, 2014).

Pentingnya pengaruh kebijakan dividen dari perusahaan maupun dari investor, bisa dikatakan perusahan yang menguntungkan jika perusahaan sanggup membayar dividen (Sari \& Sudjarni, 2015). Maka dari itu, pentingnya kebijakan dividen dalam menentukan laba yang didapatkan perusahaan harus dibagikan kepemegang saham, apa hanya akan ditahan guna membantu pertumbuhan perusahaan. selain itu, kebijakan dividen disuatu perusahaan bisa menentukan pembagian dividennya bagi pemegang saham. Indikator dalam penelitian ini yaitu likuditas, risiko bisnis, dan pertumbuhan perusahaan yang berhubungan dengan kebijakan dividen.

Likuiditas adalah raiso yang mencerminkan hubungan antara kas dan aset perusahaan lainnya dengan kewajibannya. Darmawi \& Herman (2012) berpendapat bahwa pengukuran likuditas yaitu berupa perbandingan jumlah aset lancar dengan kebutuhan likuiditas yang diprediksikan. Semakin tinggi likuiditas perusahaan, maka dividen yang dibayarkan semakin besar. Penelitian yang dilakukan Dewi \& Sedana (2018) menyatakan bahwa likuiditas mempengaruhi kebijakan deviden, namun penelitian Ginting (2018) menyatakan bahwa likuiditas tidak mempengaruhi kebijakan dividen. 
Risiko bisnis yang tinggi menyebabkan laba perusahaan menurun karena tidak mampu membiayai operasional perusahaanya. Dalam kondisi yang seperti ini bisa mengakibatkan penurunan kinerja perusahaan karena ketidakamanan keuangannya. Dengan risiko bisnis yang tinggi perusahaan akan berusaha menguatkan struktur modalnya dengan laba yang dimiliki akan ditahan sehingga akan berdampak pada penurunan dividen yang dibayarkan kepemegang sahamnya. Penelitian yang dilakukan Gakumo \& Nanjala (2016) menyatakan bahwa risiko bisnis mempengaruhi kebijakan dividen, sedangkan penelitian Mnune \& Purbawangsa (2019) mengemukakan bahwa risiko bisnis tidak mempengaruhi kebijakan dividen.

Pertumbuhan perusahan yaitu termasuk salah satu faktor yang dapat mempengaruhi kebijakan dividen. Pertumbuhan perusahaan yang berlanjutan yaitu dimana penjualan perusahaan bisa tumbuh tergantung dengan dukungan asetnya terhadap peningkatan penjualan. Selain itu, pertumbuhan penjualan juga bisa diukur dengan pertumbuhan aset bisa juga dengan kesempatan berinvestasi yang diproksikan melalui berbagai macam kombinasi nilai investment opportunity set. Pendekatan pertumbuhan perusahaan yaitu komponen untuk menilai prospek perusahaan dimasa yang akan datang. Hasil penelitian Dewi \& Sedana (2018) menyatakan bahwa pertumbuhan perusahaan mempengaruhi kebijakan dividen sedangkan, Wahyuliza \& Fahyani (2019) menyatakan bahwa pertumbuhan perusahaan tidak mempengaruhi kebijakan dividen.

Tabel 1

Rata-rata Pertumbuhan Penjualan Perusahaan Property and Real Estate tahun 2015-2019

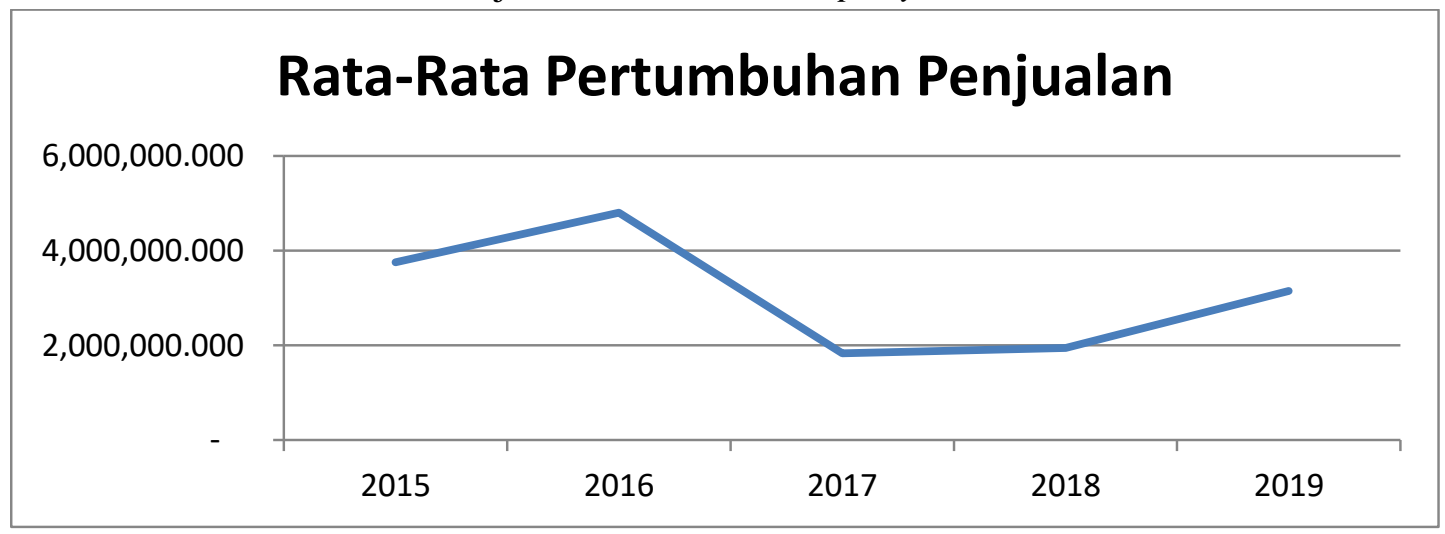

Sumber : www.idx.co.id

Tabel diatas menunjukkan data rata-rata pertumbuhan penjualan selama tahun 2015-2019 mengalami fluktuasi. Tabel 1.1 menunjukkan rata-rata pertumbuhan penjualan tahun 2015 sebesar 3.749.640,900 sedangkan pada tahun 2016 mengalami peningkatan hingga sebesar 4.794.414.300 tetapi pada tahun 2017 mengalami penurunan yang sangat drastis menjadi 1.833.194.200. Pada tahun 2018 data rata-rata pertumbuhan penjualan mengalami peningkatan menjadi 1.939.985.500 dan tahun 2019 rata-rata pertumbuhan penjualan mengalami peningkatan lagi menjadi 3.149.155.600. Artinya semakin tinggi rata-rata pertumbuhan penjualan menunjukkan bahwa investor semakin tertarik menginvestasikan dananya.

\section{Rumusan Masalah}

Berdasarkan uraian diatas, maka rumuskan masalah dalam penelitian ini sebagai berikut :

1. Apakah likuiditas, risiko bisnis dan pertumbuhan perusahaan secara simultan berpengaruh terhadap kebijakan dividen pada perusahaan property and real estate yang terdaftar di BEI tahun 2015-2019?

2. Apakah likuiditas berpengaruh terhadap kebijakan dividen pada perusahaan property and real estate yang terdaftar di BEI tahun 2015-2019?

3. Apakah risiko bisnis berpengaruh terhadap kebijakan dividen pada perusahaan property and real estate yang terdaftar di BEI tahun 2015-2019?

4. Apakah pertumbuhan perusahaan berpengaruh terhadap kebijakan dividen pada perusahaan property and real estate yang terdaftar di BEI tahun 2015-2019? 


\section{Tujuan Penelitian}

Berdasarkan rumusan masalah diatas maka tujuan dalam penelitian ini adalah sebagai berikut :

1. Untuk mengetahui apakah likuiditas, risiko bisnis dan pertumbuhan perusahaan berpengaruh terhadap kebijakan dividen pada perusahaan property and real estate yang terdaftar di BEI tahun 2015-2019.

2. Untuk mengetahui apakah likuiditas berpengaruh terhadap kebijakan dividen pada perusahaan property and real estate yang terdaftar di BEI tahun 2015-2019.

3. Untuk mengetahui apakah risiko bisnis berpengaruh terhadap kebijakan dividen pada perusahaan property and real estate yang terdaftar di BEI tahun 2015-2019.

4. Untuk mengetahui apakah pertumbuhan perusahaan berpengaruh terhadap kebijakan dividen pada perusahaan property and real estate yang terdaftar di BEI tahun 2015-2019.

\section{KAJIAN PUSTAKA DAN PEGEMBANGAN HIPOTESIS}

\section{Teori Keagenan (Agency Theory)}

Menurut Pradana \& Sanjaya (2014) menyatakan bahwa munculnya biaya keagenan dapat diperkecil dengan cara melakukan pembagian dividen kepada pemegang sahamnya, sehingga perusahaan tidak memiliki dana terlalu berlebihan yang menimbulkan peluang dapat disalahgunakan oleh berbagai pihak yang tidak bertanggung jawab. Sebagai sarana perusahaan agar investor yakin berinvestasi kembali pada perusahaannya. Pembayaran dividen bisa digunakan sebagai alat pengawasan pemegang saham pada pihak managemen perusahaan.

Pada kondisi saat ini dalam menghadapi pervasalahan perkembangan bisnis yang kaitannya dengan pengelolaan perusahaan pemilik tidak bisa mengelola sendiri, sehingga tanggung jawab pengelolaan perusahaan diserahkan pada pihak kedua. Dengan adanya keputusan ini mengakibatkan pemisahan pengendalian perusahaan dan pemisahan kepemilikan antara manajer sebagai agen dan pemilik sebagai principal. Adanya pemisahan tersebut mengakibatkan tindakan manajer tidak sesuai dengan kegiatan prinsipal. Pemberian wewenang dalam melaksanakan tugas manajerial, teori keagenan memberikan wewenang sesuai dengan kontrak yang sudah disepakati. Manajer sendiri memaksimalkan kemakmuran para pemegang saham didalam tujuan prinsipalnya. Manajer membebankan biaya kepada perusahaan sehingga mengurangi keuntungan dan pembayaran dividen (Jensen \& Meckling, 1976).

\section{Kebijakan Dividen}

Menurut Prasetyo (2017) kebijakan dividen yaitu keputusan apakah laba akan ditahan untuk pembiayaan investasi dimasa mendatang atau laba yang didapatkan perusahaan akan dibagikan kepada pemegang saham sebagai dividen. Kebijakan dividen yaitu hal yang sangat penting bagi suatu perusahaan karena melibatkan dua pihak yang memiki kepentingan yang berbeda insider dan investor. Oleh sebab itu, sebaiknya perusahaan menerapkan kebijakan dividen secara optimal dengan menggunakan stabilitas dividen saat ini serta pertumbuhan perusahaan dimasa depan dengan memaksimalkan harga sahamnya.

\section{Likuditas}

Likuditas menunjukkan bahwa kemampuan perusahaan mendanai operasional perusahaannya dan melunasi kewajiban jangka pendeknya. Likuiditas yaitu faktor penting yang perlu dipertimbangkan dalam mengambil keputusan untuk menetapkan seberapa besarnya dividen yang akan dibayar kepada para pemegang saham. Maka semakin kuatnya posisi likuiditas perusahaan maka semakin besar kemampuan untuk membayar dividen. Hal ini menunjukkan bahwa semakin kuat posisi likuiditas perusahaan pada prospek kebutuhan dana, maka akan semakin tinggi rasio pembayaran dividen (Kasmir, 2014).

\section{Risiko Bisnis}

Risiko bisnis yaitu ketidakpastian yang dihadapi suatu perusahaan dalam menjalankan bisnisnya. Risiko juga dapat dikatakan sebagai premi yang dibutuhkan untuk memperhitungkan risiko dari ketidak berhasilannya perusahaan untuk memperoleh hasil dari lingkungan dunia bisnis yang ada. Risiko bisnis yang tinggi dapat diartikan dengan kemungkinan perusahaan tidak mampu dalam membiayai operasionalnya sehingga akan menyebabkan laba menurun. Jika perusahaan memiliki risiko yang tinggi, maka perusahaan berusaha menguatkan struktur modalnya sehingga laba yang dimiliki 
perusahaan akan ditahan sehingga dapat mengakibatkan penurunan dividen yang akan dibayarkan kepada pemegang saham. Tinggi rendahnya risiko bisnis bisa dilihat dari stabilitas harganya (Epayanti \& Yadnya, 2014).

\section{Pertumbuhan Perusahaan}

Pertumbuhan yaitu seberapa jauh perusahaan tersebut dalam menempatkan diri didalam system ekonomi baik keseluruhan maupun industry yang sama. Pertumbuhan perusahaan yaitu bagaimana kemampuan perusahaan itu dalam meningkatkan sizenya. Setiap perusahaan memiliki berbagai bentuk badan usaha dalam menjalankan berbagai jenis usahanya. Mempunyai sifat yang tetap dengan tujuan memperoleh keuntungan dan laba. Pertumbuhan perusahaan yang diukur dengan growth yaitu kemampuan badan usahanya dalam mempertahankan posisi usahanya guna untuk mengembangkan industry dan ekonomi didalam perekonomian pada saat badan usaha dioperasikan dengan melihat pertumbuhan asetnya (Puteri et al., 2016).

\section{Penelitian Sebelumnya}

Studi Khan \& Ahmad (2017) melakukan penelitian dengan sampel perusahaan farmasi yang terdaftar selama tahun 2009-2014. Hasil analisis menunjukkan bahwa likuiditas, peluang pertumbuhan, dan profitabilitas mempengaruhi kebijakan dividen, tetapi perpajakan, risiko, ukuran perusahaan, dan leverage tidak mempengaruhi kebijakan dividen.

Studi Ginting (2018) dengan populasi penelitian ini adalah 45 perusahaan yang masuk kategori LQ 45 yang terdaftar di Bursa Efek Indonesia periode 2012-2016. metode yang digunakan purposive sampling jumlah sampel yang diperoleh yaitu sebanyak 16 perusahaan. Metode pengujian data menggunakan analisis regresi linier berganda. hasil penelitiannya bahwa profitabilitas mempengaruhi kebijakan dividen, sedangkan likuiditas dan leverage tidak mempengaruhi kebijakan dividen.

Studi Ratnasari \& Purnawati (2019) melakukan penelitian dengan sampel yang diambil yaitu 16 perusahaan manufaktur yang terdaftar di BEI periode 2012-2014. Metode penentuan dalam penelitian ini yaitu purposive sampling. Sampling dalam penelitian ini menggunakan metode asosiatif, teknis analisi regresi linier berganda. Menunjukkan hasil bahwa profitabilitas dan likuiditas, tingkat pertumbuhan perusahaan, dan leverage berpengaruh terhadap kebijakan dividen.

Studi Ullah \& Bagh (2019) dalam penelitiannya populasi yang digunakan yaitu perusahaan makanan non keuangan yang terdaftar di Bursa Efek Pakisan (PSE) tahun 2011-2016. Dengan sampel penelitian 20 perusahaan. hasil penelitan menunjukkan bahwa variabel profitabilitas, likuiditas dan leverage mempengaruhi kebijakan dividen, sedangkan risiko bisnis dan peluang pertumbuhan tidak mempengaruhi kebijakan dividen.

Studi Ali et al (2020) melakukan penelitian dengan sampel 55 perusahaan dengan leverage yang tinggi dari perusahaan sektor konstruksi dan property yang terdaftar di Bursa Malaysia tahun 2005-2014. Penelitian ini menggunakan analisis regresi linier berganda untuk mengevaluasi hubungan yang diajukan dalam hipotesis. Hasil penelitiannya menunjukkan leverage, likuiditas, dividend yield, dan ukuran perusahaan mempengaruhi kebijakan dividen. Tetapi variabel profitabilitas tidak mempengaruhi kebijakan dividen.

\section{Kerangka Pemikiran}

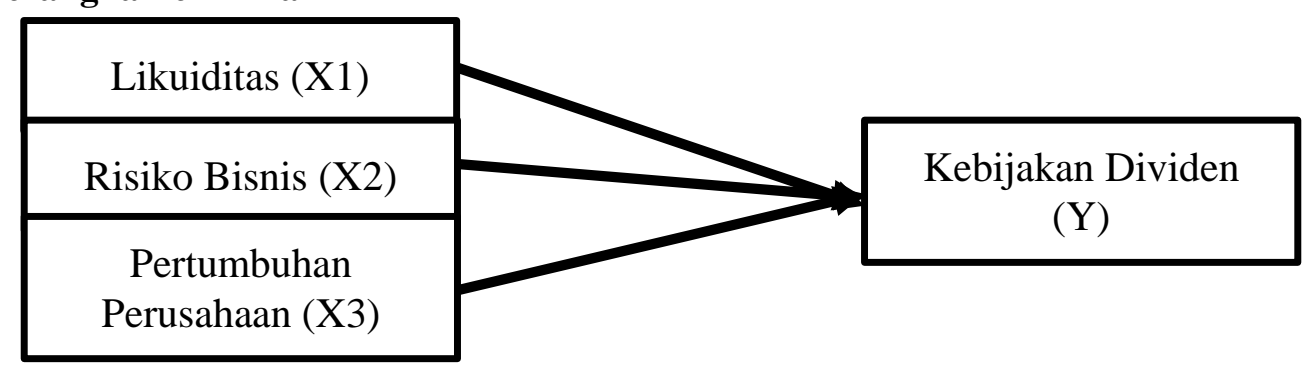

Gambar 1 Kerangka Pemikiran

\section{Pengembangan Hipotesis}

Perusahaan yang memiliki likuiditas yang tinggi menunjukkan bahwa current ratio perusahaan tersebut semakin baik, jika current rationya semakin baik berarti perusahaan mampu membayarkan kewajiban jangka pendeknya. Tetapi jika perusahaan tersebut mengalami fluktuasi atau ketidakpastian 
sehingga perusahaan mengalami kesulitan beroperasi dan kondisi keuangan yang tidak aman, maka hal tersebut bisa memungkinkan munculnya kerugian atau bisa disebut dengan risiko bisnis. Tingkat pertumbuhan perusahaan semakin tinggi berarti kebutuhan dananya juga semakin besar. Semakin besar kebutuhan dana perusahaan di masa yang akan datang maka kemungkinan besar perusahaan akan menahan keuntungannya dan tidak membayarkan sebagai dividen. Sehingga pertumbuhan perusahaan menjadi faktor yang sangat penting untuk menentukan kebijakan dividen. Berdasarkan penelitian Gakumo \& Nanjala (2016) bahwa secara simultan variabel leverage, risiko bisnis, profitabilitas dan laba per saham berpengaruh terhadap kebijakan dividen. Hal ini sejalan dengan penelitian Dewi \& Sedana (2018) yaitu variabel profitabilitas, likuiditas, ukuran perusahaan, dan tingkat pertumbuhan perusahaan mempengaruhi kebijakan dividen, dari keempat variabel secara simultan mempengaruhi kebijakan dividen.

\section{$\mathrm{H}_{1}$ : Likuiditas, Risiko Bisnis, dan Pertumbuhan Perusahaan berpengaruh terhadap kebijakan dividen}

Likuiditas yaitu sebuah perusahaan yang memenuhi kewajiban jangka pendek pada saat jatuh tempo. Investor bisa melihat kondisi keuangan perusahaannya dapat dilihat dari current ratio. Karna semakin tinggi current ratio semakin baik, dan perusahaan dapat diindikasikan jika perusahaan tersebut sanggup membayar kewajiban jangka pendeknya. Dalam penelitian Dewi \& Sedana (2018) menunjukkan bahwa likuiditas mempengaruhi kebijakan deviden.

\section{$\mathrm{H}_{2}$ : Likuiditas berpengaruh terhadap kebijakan deviden}

Risiko yaitu kondisi dimana suatu perusahaan yang memungkinkan munculnya kerugian, risiko bisnis yaitu ketidakstabilan perusahaan sehingga bisa menyebabkan perusahaan akan mengalami kesulitan dalam beroperasi dan keuangan perusahaannya yang tidak aman. Gakumo \& Nanjala (2016) berpendapat risiko bisnis mempengaruhi kebijakan dividen.

\section{$\mathrm{H}_{3}$ : Risiko bisnis berpengaruh terhadap kebijakan deviden Pengaruh}

Pertumbuhan perusahaan merupakan suatu tujuan yang dinantikan pihak eksternal maupun internal karena bisa memberikan dampak yang bagus bagi perusahaan itu sendiri ataupun bagi pihak yang memiliki kepentingan pada perusahaan seperti kreditur, investor, dan para pemegang sahamnya. Dewi \& Sedana (2018) berpendapat pertumbuhan perusahaan mempengaruhi kebijakan dividen.

\section{$\mathrm{H}_{4}$ : Pertumbuhan perusahaan berpengaruh terhadap kebijakan deviden}

\section{METODE PENELITIAN}

Metode yang digunakan yaitu penelitian kuantitatif. Sugiyono (2017) Penelitian kuantitatif yaitu sebagai penelitian yang berlandaskan filsafat positif, dan bisa untuk meneliti sampel atau populasi tertentu, pengumpulan data menggunakan instrument penelitian, analisis data bersifat kuantitatif atau statistic, bertujuan menguji hipotesis yang sudah ditentukan. Sumber data penelitian ini yaitu data sekunder yang berupa laporan keuangan perusahaan property dan real estate yang diakses dari www.idx.co.id dan responden perusahaan property and real estate yang terdaftar di BEI periode 20152019. Populasi penelitian ini yaitu semua perusahan property and real estate yang terdaftar di BEI dan mempublikasikan laporan keuangannya selama periode 2015-2019 berdasarkan dengan kriteria tertentu mendapatkan sampel 50 perusahaan dengan 4 perusahaan yang teroutlier sehingga sampel perusahaan menjadi 46 perusahaan.

\section{Variabel Penelitian dan Pengukurannya}

Variabel dependennya yaitu kebijakan dividen. Kebijakan dividen untuk menentukan apakah labanya dibagikan kepada pemegang saham atau akan digunakan untuk pembiayaan investasi sebagai laba yang ditahan dan akan digunakan dimasa yang akan datang (Prasetyo, 2017). Kebijakan dividen bisa dihitung dengan Dividend Payout Ratio (DPR) :

$$
\mathrm{DPR}=\frac{\text { Dividen }}{\text { Pendapatan bersih }}
$$




\section{Likuiditas}

Current Ratio (CR) yaitu ratio untuk mengetahui kesanggupan perusahaan dalam memenuhi liabilitas jangka pendeknya. (Sari et al, 2016) Rumusnya :

$$
\mathrm{CR}=\frac{\text { Aktiva lancar }}{\text { Hutang lancar }}
$$

\section{Risiko Bisnis}

Rafique (2012) mengemukakan bahwa risiko bisnis bisa dihitung dengan rumus :

Risiko Bisnis $=$ Earning Before Interest and Tax (EBIT)

$$
\text { Total Aset }
$$

\section{Pertumbuhan Perusahaan}

Pertumbuhan perusahaan (growth) yaitu kemampuan badan usaha dalam mempertahankan posisi usaha perkembangan ekonomi dan industri dalam perekonomian dengan melihat pertumbuhan asetnya pada saat badan usaha beroperasi (Puteri, 2016). Rumusnya :

$$
\text { Growht }=\underline{\text { Total Asset }}{ }_{t}-\text { Total Asset }_{\mathrm{t}-1}
$$

Total Asset ${ }_{\mathrm{t}-1}$

\section{HASIL DAN PEMBAHASAN}

\section{Deskripsi Umum Data Penelitian}

Dalam penelitian ini, ditemukan empat variabel yaitu likuiditas, risiko bisnis, dan pertumbuhan perusahaan terhadap kebijakan dividen pada perusahaan property and real estate yang terdaftar di BEI tahun 2015-2019. Sumber data yang digunakan yaitu data sekunder yang diperoleh dari www.idx.co.id dengan menggunakan metode puposive sampling dengan pengambilan sampling berdasarkan beberapa kriteria tertentu.

\section{Statistik Deskriptif}

\begin{tabular}{|c|c|c|c|c|c|}
\hline & $\mathrm{N}$ & Minimum & Maximum & Mean & Std. Deviation \\
\hline CR & 46 & ,879 & 7,760 & 2,61598 & 1,409749 \\
\hline RB & 46 &, 012 &, 141 & ,07787 & ,031307 \\
\hline GROWTH & 46 & ,004 & 277 & ,11426 &, 060030 \\
\hline DPR & 46 & ,002 & ,119 & ,04063 & ,024888 \\
\hline $\begin{array}{l}\text { Valid N } \\
\text { (listwise) }\end{array}$ & 46 & & & & \\
\hline
\end{tabular}

Tabel 2

Hasil Uji Statistik Deskriptif

Hasil statistik deskriptif menunjukkan bahwa variabel CR nilai minimum sebesar 0,879 nilai maximum sebesar 7,760 dengan mean 2,61598 dan std.deviation sebesar 1,409749. Variabel RB menunjukkan bahwa nilai minimum sebesar 0,012 nilai maximum 0,141 dengan mean 0,07787 dan std.deviation 0,031307. Variabel GROWTH nilai minimum 0,004 nilai maximum 0,277 dengan mean 0,11426 dan std.deviation 0,060030. Variabel DPR menunjukkan bahwa nilai minimum 0,002 nilai maximum 0,119 dengan mean 0,040063 dan std.deviation 0,024888. 


\section{Uji Asumsi Klasik}

Uji Normalitas

Tabel 3

Hasil Uji Normalitas

\begin{tabular}{lccc}
\hline & $\begin{array}{c}\text { Unstandardized } \\
\text { Residual }\end{array}$ & Std & Keterangan \\
\hline $\begin{array}{l}\text { Kolmogrov- } \\
\text { smirnov Z } \\
\begin{array}{l}\text { Asymp.Sig.(2- } \\
\text { tailed) }\end{array}\end{array}$ & 0,400 & $>0,05$ & Data terdistribusi normal \\
\hline
\end{tabular}

Berdasarkan hasil uji normalitas menggunakan uji One-Sample Kolmogorov-Smirnov Test diatas menunjukkan hasil nilai Asymp.sig (2- tailed) 0,400 menunjukkan bahwa nilai Asymp.sig (2tailed) lebih besar dari 0,05 maka disimpulkan data terdistribusi normal.

\section{Uji Autokorelasi}

Tabel 4

Hasil Uji Autokorelasi

\begin{tabular}{cccc}
\hline Variabel & Asymp. Sig. (2-tailed) & Standar & Keterangan \\
\hline $\begin{array}{c}\text { Unstandardized } \\
\text { Residual }\end{array}$ & 0,456 & $>0,05$ & Tidak Terjadi Autokorelasi \\
\hline
\end{tabular}

Berdasarkan hasil pengujian autokorelasi diperoleh nilai probabilitas Asymp. Sig. (2- tailed) 0,456 lebih besar dari 0,05, disimpulkan tidak terjadi autokorelasi.

\section{Uji Multikolinearitas}

Tabel 5

Hasil Uji Multikolinearitas

\begin{tabular}{clllll}
\hline Variabel & Tolerance & Std & VIF & Std & Keterangan \\
\hline CR & 0,986 & $>0,1$ & 1,015 & $<10$ & Bebas Multikolinearitas \\
RB & 0,957 & $>0,1$ & 1,045 & $<10$ & Bebas Multikolinearitas \\
GROWTH & 0,970 & $>0,1$ & 1,031 & $<10$ & Bebas Multikolinearitas \\
\hline
\end{tabular}

Hasil dari uji multikolinearitas memperoleh nilai tolerance variabel CR sebesar 0,986 variabel RB sebesar 0,957 variabel GROWTH 0,970. Sedangkan untuk nilai VIF variabel CR 1,015 variabel RB 1,045 dan variabel GROWTH 1,031. Nilai tolerance untuk semua variabel $>0,1$ dan nilai VIF semua variabel $<10$, maka disimpulkan hasil pengujiannya menyatakan data yang dianalisis memenuhi asumsi klasik multikolinearitas.

\section{Uji Heteroskedastiditas}

Tabel 6

Hasil Uji Heteroskedastiditas

\begin{tabular}{|c|c|c|c|}
\hline Variabel & $\begin{array}{c}\text { Unstadardized } \\
\text { Residual }\end{array}$ & Koefisien & Keterangan \\
\hline CR & 0,721 & $>0,05$ & Tidak terjadi Heteroskedastisidas \\
\hline RB & 0,450 & $>0,05$ & Tidak terjadi Heteroskedastisidas \\
\hline GROWTH & 0,641 & $>0,05$ & Tidak terjadi Heteroskedastisidas \\
\hline
\end{tabular}

Hasil uji heteroskedastisitas menunjukksn bahwa nilai probabilitas signifikansi dari masingmasing variabel adalah CR 0,721 RB 0,450 dan GROWTH 0,641. Hasil tersebut menunjukkan bahwa nilai probabilitas signifikasi lebih besar dari 0,05 . Maka disimpulkan model regresi tidak terjadi heteroskedastisitas. 


\section{Uji Regresi Linier Berganda}

Tabel 7

Uji Model Regresi

\begin{tabular}{cc}
\hline Variabel & B \\
\hline Konstanta & 0,010 \\
CR & 0,007 \\
RB & 0,262 \\
GROWTH & $-0,058$ \\
\hline
\end{tabular}

Kebijakan Dividen $=0,010+0,007 \mathrm{CR}+$ 0,262 RB $-0,058$ GROWTH $+\mathrm{e}$

1) Nilai konstanta sebesar 0,010 (positif). Nilai tersebut bisa diartikan bahwa kebijakan dividen (DPR) akan bernilai 0,010 jika masing-masing variabel Current Ratio (CR), Risiko Bisnis (RB), dan Pertumbuhan Perusahaan (GROWTH) bernilai 0.

2) Current Ratio (CR) memiliki koefisien regresi 0,007 yang berarti setiap kenaikan 1 satuan Current Ratio (CR) dengan asumsi variabel lain tetap maka akan menaikkan kebijakan dividen sebesar 0,007 .

3) Risiko Bisnis (RB) memiliki koefisien regresi 0,262 yang berati setiap kenaikan 1 satuan Risiko Bisnis (RB) dengan asumsi variabel lain tetap maka akan menaikkan kebijakan dividen sebesar 0,262 .

4) Pertumbuhan Perusahaan (GROWTH) mempunyai koefisien regresi -0,058 yang berarti setiap kenaikan 1 satuan Pertumbuhan Perusahaan $(G R O W T H)$ dengan asumsi variabel lain tetap maka akan menurunkan kebijakan dividen sebesar 0,058.

\section{Uji Kelayakan Model (Uji F)}

Tabel 8

Hasil Uji Kelayakan Model (Uji F)

\begin{tabular}{clllll}
\hline Model & F hitung & F tabel & Sig & Standar & Keterangan \\
\hline Regresi Linier Berganda & 5,340 & 3,214 & 0,003 & $<0,05$ & Model layak
\end{tabular}

Berdasarkan $\mathrm{F}$ tabel dapat dilihat dari $\mathrm{F}$ pada tingkatan signifikansi 0,05 dengan df 1 (jumlah variabel -1$)=3-1=2$, dan df $2=\mathrm{n}-\mathrm{k}-1$ dimana $\mathrm{n}$ yaitu jumlah data penelitian $\mathrm{k}$ variabelnya, maka $46-2-1=43$. Maka memperoleh $\mathrm{F}$ tabel sebesar 3,214 angka ini diperoleh dari $\mathrm{f}$ tabel. Hasil pengujian memperoleh $\mathrm{F}$ hitung $>\mathrm{F}$ tabel $(5,340>3,214)$ dan signifikansi $<0,05(0,003<0,05)$, sehingga disimpulkan model regresi layak digunakan.

\section{Uji Hipotesis}

Tabel 9

Hasil Uji Hipotesis (Uji T)

\begin{tabular}{|c|c|c|c|c|c|}
\hline Variabel & T hitung & T tabel & Sig. & Std & Keterangan \\
\hline $\mathrm{CR}$ & 2,805 & $>2,018$ & 0,008 & $<0,05$ & H1 Diterima \\
\hline $\mathrm{RB}$ & 2,454 & $>2,018$ & 0,018 & $<0,05$ & H2 Diterima \\
\hline GROWTH & $-1,046$ & $<-2,018$ & 0,301 & $>0,05$ & H3 Ditolak \\
\hline
\end{tabular}

a. Variabel Current Ratio (CR) menunjukkan hasil diterima, berarti variabel Current Ratio (CR) berpengaruh terhadap kebijakan dividen.

b. Variabel Risiko Bisnis (RB) menunjukkan hasil diterima, berarti variabel Risiko Bisnis (RB) berpengaruh terhadap kebijakan dividen.

c. Variabel Pertumbuhan Perusahaan $(G R O W T H)$ menunjukkan hasil ditolak, berarti variabel Pertumbuhan Perusahaan (GROWTH) tidak berpengaruh terhadap kebijakan dividen. 
Hasil Uji Koefisien Determinan $\left(\mathrm{R}^{2}\right)$

\begin{tabular}{cll}
\hline Model & Adjusted R squer & Keterangan \\
\hline 1 & 0,224 & $\begin{array}{l}\text { variabel dependen dapat dijelaskan oleh } \\
\text { variabel independen }\end{array}$ \\
\hline
\end{tabular}

Hasil uji koefisien determinan $\left(\mathrm{R}^{2}\right)$ menyatakan nilai adjusted $\mathrm{r}$ squer 0,224 yang berarti variabel dependen penelitian ini bisa dijelaskan oleh variabel independen sebesar $22,4 \%$ sementara sisanya $77,6 \%$ dipengaruhi oleh variabel lain.

\section{HASIL PENELITIAN DAN PEMBAHASAN}

\section{Pengaruh likuiditas, risiko bisnis, dan pertumbuhan perusahaan terhadap kebijakan dividen}

Hasil pengujian kelayakan model (Uji F) memperoleh hasil semua variabel independen yaitu likuiditas, risiko bisnis, pertumbuhan perusahaan secara simultan berpengaruh terhadap variabel dependen yaitu kebijakan dividen. Sejalan dengan penelitian Dewi \& Sedana (2018) berpendapat bahwa secara simultan variabel independen berpengaruh terhadap variabel dependen yaitu kebijakan dividen. Sejalan juga dengan penelitian Gakumo \& Nanjala (2016) yang berpendapat secara simultan variabel independen berpengaruh terhadap kebijakan dividen. Namun bertentangan dengan penelitan Khan \& Ahmad (2017) yang berpendapat bahwa hanya likuiditas yang berpengaruh terhadap kebijakan dividen.

\section{Pengaruh likuiditas terhadap kebijakan dividen}

Hasil pengujian variabel likuiditas menunjukkan bahwa likuiditas berpengaruh terhadap kebijakan dividen. Sejalan dengan penelitian Dewi \& Sedana (2018) yang berpendapat likuiditas berpengaruh terhadap kebijakan dividen. Namun bertentangan dengan penelitian Ginting (2018) yang berpendapat likuiditas tidak berpengaruh terhadap kebijakan dividen. Semakin tinggi current rationya maka semakin baik, karena dapat menguntungkan investor dengan perusahaan sanggup membayar liabilitas jangka pendeknya. Keadaan likuiditas dalam suatu perusahaan sangat mempengaruhi kebijakan dividennya. Dengan kas yang lebih besar, maka perusahaan tersebut cenderung akan membagikan dividennya dibandingkan dengan perusahaan yang memiliki kas sedikit.

\section{Pengaruh risiko bisnis terhadap kebijakan dividen}

Hasil pengujian variabel risiko bisnis menunjukkan bahwa risiko bisnis berpengaruh terhadap kebijakan dividen. Sejalan dengan penelitian Gakumo \& Nanjala (2016) yang menunjukkan risiko bisnis berpengaruh terhadap kebijakan dividen. Namun bertentangan dengan penelitian Ullah \& Bagh (2019) yang berpendapat risiko bisnis tidak berpengaruh terhadap kebijakan dividen. Risiko bisnis yang tinggi dapat memungkinkan tidakmampunya perusahaan membiayai opersional perusahaannya yang berdampak laba menurun. Risiko bisnis yang tinggi perusahaan berusaha menguatkan struktur modalnya sehingga laba yang dimiliki perusahaan ditahan, tetapi dampaknya pada pembayaran dividen kepada pemegang saham menurun. Dalam hal ini perusahaan berusaha mempertahankan labanya dalam bentuk laba ditahan sebagai sumber pendanaan internal.

\section{Pengaruh pertumbuhan perusahaan terhadap kebijakan dividen}

Hasil pengujian variabel pertumbuhan perusahaan menunjukkan bahwa pertumbuhan perusahaan tidak berpengaruh terhadap kebijakan dividen. Sejalan dengan penelitian Wahyuliza \& Fahyani (2019) berpendapat pertumbuhan perusahaan tidak berpengaruh terhadap kebijakan dividen. Namun bertentangan dengan penelitian Dewi \& Sedana (2018) berpendapat pertumbuhan perusahaan berpengaruh terhadap kebijakan dividen. Dapat diartikan meskipun sumber pendanaan internal perusahaan telah digunakan sedangkan dana yang dipakai untuk pertumbuhan perusahaan tidak cukup, perusahaan tersebut dapat menggunakan sumber pendanaan eksternalnya. Tumbuh tidaknya perusahaan tidak akan berpengaruh dengan keputusan perusahaan dalam membagikan dividennya.

\section{KESIMPULAN}

Penelitian ini bertujuan untuk mengetahui pengaruh likuiditas, risiko bisnis, dan pertumbuhan perusahaan terhadap kebijakan dividen. Populasi dalam penelitian ini yaitu perusahaan property and real estate yang terdaftar di Bursa Efek Indonesia tahuan 2015-2019. Metode yang digunakan yaitu purposive sampling memperoleh sampel sejumlah $10 \times 5=50$ perusahaan, tetapi setelah 
didapatkan bahwa data terdistribusi tidak normal maka dilakukan uji outlier, uji outlier dilakukan dengan dengan melihat grafik boxplot, angka-angka yang terletak diluar boxplot merupakan angka observasi yang harus dihilangkan. Sebelum dilakukannya outlier terdapat 50 perusahaan yang menjadi sampel dalam penelitian ini, tetapi setelah dilakukannya outlier terdapat 4 perusahaan dengan angka diluar boxplot sehingga jumlah sampelnya menjadi 46 perusahaan. Berdasarkan hasil analisis regresi linier berganda dapat disimpulkan bahwa likuiditas yang diukur dengan menggunakan Current Ratio (CR) berpengaruh terhadap kebijakan dividen, risiko bisnis berpengaruh terhadap kebijakan dividen. Sedangkan pertumbuhan perusahaan yang diukur dengan growth tidak berpengaruh terhadap kebijakan dividen.

\section{KETERBATASAN}

1. Variabel dalam penelitian ini terbatas pada variabel kebijakan dividen, likuiditas, risiko bisnis, dan pertumbuhan perusahaan.

2. Sampel penelitian ini hanya fokus pada sub sektor property and real estate dengan periode 5 tahun yaitu tahun 2015-2019.

\section{SARAN}

Berdasarkan keterbatasan, peneliti memberikan saran bagi peneliti selanjutnya sebagai berikut:

1. Mengganti atau menambah variabel yang dimungkinkan berpengaruh terhadap kebijakan dividen seperti profitabilitas, leverage, ukuran perusahaan, struktur modal, dan lain-lain.

2. Penelitian selanjutnya disarankan untuk melakukan penelitian pada sub sektor lain, tidak hanya pada sub sektor property and real estate.

\section{REFERENSI}

Ali, N. Y., Mohamad, Z., \& Samah, A. R. A. S. (2020). What Determines Dividend Policy in High Leverage Firms in Malaysia? International Journal of Advanced Research in Economics and Finance, 2(2), 123-132.

Dewi, I. A., \& Sedana, I. B. (2018). Faktor-Faktor Yang Mempengaruhi Kebijakan Dividen Pada Perusahaan Manufaktur Di Bursa Efek Indonesia. E-Jurnal Manajemen Universitas Udayana, 7(7), 3623. https://doi.org/10.24843/ejmunud.2018.v07.i07.p07

Enow, S. T., \& Isaacs, E. B. (2018). Factors that Determine Dividend Payout . Evidence from the Financial Service Sector in South Africa. Journal of Banking and Finance Management, 1(1), 4853.

Epayanti, A., \& Yadnya, I. P. (2014). Pengaru Ukuran Perusahaan terhadap Profitabilitas serta Kebijakan Dividen. E-Jurnal Manajemen Universitas Udayana, 3 (12), 3488-3502.

Gakumo, S. T., \& Nanjala, D. C. (2016). Factors Influencing Dividend Payout Decision of Financial and Non-Financial Companies Listed on Nairobi Securities Exchange. American Journal of Finance, 1(2), 16-28. https://doi.org/10.47672/ajf.116

Ghozali, I. (2013). Aplikasi Analisis Multivariate dengan Program IBM SPSS 21 Update PLS Regresi. Semarang : Badan Penerbit Universitas Diponegoro.

Ginting, S. (2018). Pengaruh Likuiditas, Profitabilitas. Dan Leverage Terhadap Kebijakan Deviden Pada Perusahaan LQ46 Yang Terdaftar Di Bursa Efek Indonesia Periode 2012-2016. Jwem Stie Mikroskil, 8(2), 195-204.

Kasmir. (2014). Analisis Laporan Keuangan, Cetakan ke-7 (pertama). Jakarta : PT Raja Grafindo Persada.

Khan, F. A., \& Ahmad, N. (2017). Determinants of dividend payout: An empirical study of pharmaceutical companies of Pakistan stock exchange (PSE). Journal of Financial Studies \& Research, 2017(29017), 1-16. https://doi.org/10.5171/2017.538821

Mnune, T. D., \& Purbawangsa, I. B. A. (2019). Pengaruh Profitabilitas, Leverage, Ukuran Perusahaan Dan Risiko Bisnis Terhadap Kebijakan Dividen Pada Perusahaan Manufaktur. E-Jurnal $\begin{array}{llll}\text { Manajemen Universitas } & \text { Udayana, } & 862 .\end{array}$ https://doi.org/10.24843/ejmunud.2019.v08.i05.p10

Murni, S., \& Andriana. (2007). Pengaruh Insider Ownership, Institusional Investor, Dividen Payment, dan Firm Growth terhadap Kebijakan Hutang Perusahaan. Media Riset Akuntansi, 1, 3, 1-26. 
Pradana, S. W., \& Sanjaya, I. P. (2014). Pengaruh Profitabilitas, Free Cash Flow, dan Investment Opportunity Set terhadap Dividend Payout Ratio. Universitas Atma Jaya Yogyakarta. SNA 17 Mataram.

Prasetyo, F. A. (2017). Sains Undercover: Memahami apa yang Tersembunyi dari Sains dengan Cara Lain. Yogyakarta : Diandra Kreatif.

Puteri, I. M., Sudarto, \& Sulistyandari. (2016). Analisis Pengaruh Likuiditas , Profitabilitas , Insider Ownership , Institutional Ownership dan Pertumbuhan Perusahaan terhadap Kebijakan Dividen pada Perusahaan Sektor Properti, Real Estate dan Konstruksi Bangunan. Jurnal Ekonomi Dan Bisnis Islam, Universitas Jenderal Soedirman, 2(1), 41-54.

Rafique, M. (2012). Factors Affecting Dividend Payout: Evidence From Listed Non-Financial Firms of Karachi Stock Exchange (c) Society for Business and Management Dynamics ( Society for Business and Management Dynamics. Business Management Dynamics, 1(11), 76-92.

Ratnasari, P. S., \& Purnawati, N. K. (2019). Pengaruh Profitabilitas, Likuiditas, Tingkat Pertumbuhan Perusahaan Dan Leverage Terhadap Kebijakan Dividen. E-Jurnal Manajemen Universitas Udayana, 8(10), 6179. https://doi.org/10.24843/ejmunud.2019.v08.i10.p16

Sari, K. A., \& Sudjarni, L. K. (2015). Pengaruh Likuiditas, Leverage, Pertumbuhan Perusahaan, Dan Profitabilitas Terhadap Kebijakan Dividen Pada Perusahaan Manufaktur Di Bei Komang. EJurnal Manajemen Unud, 4(10), 3346-3374.

Sari, M. R., Oemar, A., \& Andini, R. (2016). Pengaruh Pertumbuhan Perusahaan, Ukuran Perusahaan, Earning Per Share, Current Ratio, Return On Equity Dan Debt Equity Ratio Terhadap Kebijakan Dividen. Journal of Accounting, 2(2).

Sartono, A. (2014). Manajemen Keuangan: Teori dan Aplikasi (Empat). BPFE.Yogyakarta

Sugiyono. (2017). Metode Penelitian Kuantitatif, Kualitatif, dan R\&D. Bandung : Alfabeta, CV.

Supriyono, R. A. (2018). Akuntansi Keprilakuan. Yogyakarta : Gajah Mada University Press.

Ullah, K., \& Bagh, T. (2019). Finance and Management Scholar at Riphah International University Islamabad, Pakistan, Faculty of Management Sciences. 10(5), 12-28. https://doi.org/10.7176/RJFA

Wahyuliza, S., \& Fahyani, R. (2019). Pengaruh Pertumbuhan Perusahaan, Ukuran Perusahaan, Struktur Modal Dan Return on Equity Terhadap Kebijakan Dividen Pada Perusahaan Manufaktur Yang Terdaftar Di Bursa Efek Indonesia. Jurnal Benefita, 1(1), 78. https://doi.org/10.22216/jbe.v1i1.3388 